\title{
Attitude of Parents-Teachers towards the use of Instructional Technology in Teaching Numeracy to Children with Mild Intellectual Disability: A Case of Penang Malaysia
}

\author{
Taibat Bolanle Adiat ${ }^{1 *}$, Aznan Che Ahmad ${ }^{1}$, Munirah Ghazali ${ }^{1}$ \\ ${ }^{1}$ (School of Educational Studies, Universiti Sains Malaysia, Pinang)
}

\begin{abstract}
Integrating instructional technology into teaching and learning numeracy for the individual with mild intellectual disability not only make teachers' job easier but also impose a responsibility on them. This study investigates attitude of parents-teachers towards the use of instructional technology in teaching numeracy to children with mild intellectual disability in Penang Malaysia. The study adopted pure descriptive method and the sample comprised sixty participants. It was revealed from the result of the study that students with mild intellectual disability parents and teachers are familiar with usage of computer. More so, there was no significant difference between the teachers and parents. However, female teachers have higher mean compare to that of male teachers, and also, female parents have higher mean than male parents on the use of instructional technology in assisting the learning of their children at home. It is therefore, recommended that parents and teachers should keep it up with the use of computer and other instructional technology in teaching and learning children with mild intellectual disability.
\end{abstract}

Keywords: Parents and teachers' attitude, Instructional technology, Children with mild intellectual disability

\section{INTRODUCTION}

It is a known fact that the use of instructional technology in teaching numeracy to the children particularly those with mild intellectual disability has become more prevalent in the world due to its impacts to educational setting. Uzma (2001) maintained that Instructional technology or educational technology serve as the instructional aids and techniques used by the trainers or teachers in order to improve the process of human learning. It is also an effort of using available machines to manipulate the environment of individuals with the hope of generating changes in behaviors or other learning outcome. Instructional technologies not only make teachers' job easier but also impose a responsibility on them. This is because integrating technology into teaching and learning has always changed the instructional program me, learning-teaching process and learning styles of the students so that teachers have to adapt to that change (Rose and Mayer, 2000).

Computer can be used as an effective learning tool to support the acquisition of basic learning skills Krewinkel (2006). Meanwhile, instructional materials has had a tremendous impact in the classroom and the emphasis was on students access to numerical information outside the classroom and improved students with mild intellectual disability motivation, not only on specific academic achievement in fact, fewer than half of the teachers used computers for numerical purposes rather than word- processing, spreadsheets or graphics for personal productivity. Keil (2008) stated that children acquire most of what they know secondhand, through others and most of the knowledge occurs in many nonschool settings such as through television, museums, toys and other artifacts, the Internet, or even in various games and activities such as chess, cooking, or running a lemonade stand.

It has been recognized that through the use of instructional technology interaction among the children with mild intellectual disability would be established and essentially to activities in which more individualized instructor-students interaction is needed as a result, their level of socialization would be improved. However, the efficacy of the use of instructional technology to children with mild intellectual disability will largely be determined by the attitude of both teachers and parents of these children. Christensen, 2002; Vannatta \& Fordham, (2004) maintained that teachers' attitudes and experience are factors associated with computer use. Both positive attitudes about technology and technology skills in combination are accepted precursors for effective use of technology (Migliorino \& Maiden, 2004).

Also, Smith and Shotsberger (2001) observed that both male and female teachers identified instructional technology as important in mathematics education to assist in the development of concepts, but those same people were uncomfortable in discussing the specific uses of technology for instruction due to a lack of knowledge. Consequently therefore, this study wants to find out the attitude of parents and teachers on the use of instructional technology in teaching and learning numeracy to children with mild intellectual disability in Penang, Malaysia. 


\section{Theoretical Perspectives}

Technology use in education is becoming an increasingly important part of higher and professional education (Wernet, Olliges, \& Delicath, 2000; Almekhlafi, 2006a, 2006b). Technology not only gives learners with mild intellectual disability the opportunity to control their own learning process, but also provides them with ready access to a vast amount of information over which the teachers and parents have no control (Lam \& Lawrence, 2002). Moreover, instructional technology is an increasingly influential factor in mathematical education and developing new ways of learning that gives children with intellectual disability the opportunity to choose what they are interested in learning. Kumeria \&Rao (2004) see the utilization of instructional technology not only supportive but also effective for qualitative teaching and learning of number processing.

On the other hands, Singh (2005) believed that instructional technology acts as a stimulant in augmenting the efficiency of the whole numeracy teaching and learning process. However, the use of instructional technology is an important tool in the teaching and learning process. National Council of Teachers Mathematics, (2000) noted that technology is essential in teaching and learning mathematics which influences mathematical taught as well as enhancing students' learning.

As a result of this therefore, special education teachers' and parents' attitudes play important roles in using technology for teaching and learning mathematics. It is very important to improve teachers and parents' attitudes towards using computers in the classroom and home because it may enhance mathematics teaching and learning. Unfortunately, many male and female special education teachers are or at least perceive themselves to be ill-prepared to do so (Doering, Hughes \& Huffman, 2003; National School Board Foundation (NSBF), 2002). Hence, teacher education programs have been criticized regarding to how they have endeavored to prepare special education teachers to infuse technology into their repertoire of instructional strategies. Teacher educators, in turn, have been accused of failing to practice what they preach when it comes to the use of technology-based instructional methods (Hardy, 2003).

The failure to teach with technology while advocating the benefits of such methods are especially disappointing because special education teachers' attitudes about teaching with technology as well as their sense of preparedness for and commitment to do so can be enhanced via the observation of instructors who effectively teach with technology (Buckenmeyer \& Freitas, 2007; Mills \& Tincher, 2003; Pope, Hare \&Howard, 2002; Snider 2002). The National Education Policy 1998-2010 opined that the inclusion of special education teachers serve as quality inputs for the improvement of the quality of education. However, male and female special education teachers are unfamiliar with the types of technology available for teaching.

Also, male special education teachers lack the knowledge of how to properly incorporate technology in the classroom compare to female counterpart (Doering, Huffman, \& Hughes, 2003). Furthermore, Instructional technology has tremendous potential for enhancing mathematics instruction (Roschelle, Pea, Hoadley, Gordin, \& Means, 2000). As well as useful in strengthening children with mild intellectual disability learning, assisting in developing mathematical concepts and enriching their learning in the areas of richer curricula, enhanced pedagogies and more effective organizational structures (Dede, 2000).

Although, instructional technology has not reached its potential in male and female special education teachers' instruction such as female special education teachers often do not have the experience of using computers in the classroom or knowledge about available software compare to male counterpart (Gunter, 2001). Meanwhile, Diem (2000) maintained that both male and female special education teachers hardly use computers themselves due to lack of support and little free time to learn the often-complicated operation of technological devices. Powers and Blubaugh (2005) observed that female special education teachers are well versed in the issues and applications of technology than male.

In another development, Marsh et.al (2005) found that parents considered their children to lead generally well balanced lives, with popular culture, media and new technologies playing an important, but not overwhelming role in their leisure activities. Weber (2006) reported that parents were comfortable or very comfortable with their young children watching television and videos, and comments that parents readily accept and even accommodate this trend of infant and toddler media use. In the same vein, Parents see themselves as principal agents of children's socialization as they are able to transfer their own attitudes and beliefs in their children, through their counseling and guidance to engage in specific activities as well as the occasions that provide opportunities for their children (Shashaani and Kahlili, 2001'Sutherland et al., 2000).

Rideout and Hamel, (2006) observed that male and female parents find media a tremendous benefit in parenting and cannot imagine how they'd get through the day without it. In a similar judgment, Soeters \& Van Schaik, 2006; Subrahmanyam et al. (2001) noted that female parents see computer technology as a positive evolution for their children's life and achievement than male parents. 


\section{Hypotheses}

Three null hypotheses were postulated at the significant level of .05; they are:

$\mathrm{H}_{01}$ : There is no significant difference between parents and teacher in their attitudes towards the use of instructional technology in teaching numeracy to children with mild intellectual disability.

$\mathrm{H}_{02}$ : There is no significant difference between male and female teachers in their attitudes toward the use of instructional technology in teaching numeracy to children with mild intellectual disability.

$\mathrm{H}_{03}$ : There is no significant difference between male and female parents in their attitudes towards the use of instructional technology in teaching numeracy to children with mild intellectual disability.

\section{Method}

Pure descriptive method was deemed suitable for this study to gather the data. The sample comprised thirty parents and thirty teachers of students with mild intellectual disability in Penang, Malaysia. Respondents were selected using simple random sampling selection.

\section{Instrument}

A set of questionnaire was used as the main instrument of this study to measure the attitude of parents and teachers towards the use of instructional technology in teaching numeracy to children with mild intellectual disability. This instrument adopted from Albirini (2004). The instrument was modified in other to suit this study. The scale consisted of twenty questions for the teachers and the parents of children with mild intellectual disability. The questionnaire was accompanied by four-point Likert scales of Strongly Disagree (SD), Disagree (D), Agree (A) and Strongly Agreed (SA) format.

\section{Analysis of data}

The data was analyzed by using both the descriptive statistics and the independent t-test techniques. The software utilized for the data analysis was the statistics package for social scientists (spss) version 20. In the descriptive statistics the percentage scores on ten dependent variables that involved include: (1) there is no reason for using computer (2) computer is taking much time for using (3) I familiar with the use of computer (4) computer serves as tools for support teaching and learning, (5) computer makes teaching to be effective (6) computer is difficult to understand, (7) Computer requires Mental effort, (8) computer is uncomfortable for teaching , (9) computer is inability to monitor students learning , (10) Enjoy using computer. All these variables are analyzed for parent and teachers. Furthermore, t-test techniques were used in comparing analysis of teachers and parents, teachers based on gender and parents according to gender. The independent $t$-test was carried out at 0.05 level of significance (i.e. alpha value of 0.05). The results of the t-test formed the basis for accepting or rejecting the hypothesis of the study. Therefore, the result of the analysis of the study presented below.

\section{Results}

Descriptive statistics on a parents and teachers attitude towards the use of instructional technology in teaching numeracy to children with mild intellectual disability base

\begin{tabular}{cccccc}
\hline Variables & Groups & $\mathrm{N}$ & Mean & Std. Deviation & $\%$ \\
\hline \multirow{2}{*}{ There is no reason for using computer } & parent & 30 & 1.90 & 1.094 & $48.3 \%$ \\
computer is taking much time in & teachers & 30 & 1.80 & .887 & $40 \%$ \\
teaching & parent & 30 & 1.70 & .877 & $61.7 \%$ \\
& teachers & 30 & 1.83 & .834 & $56.7 \%$ \\
I am not familiar with computer & parent & 30 & 3.30 & .877 & $66.7 \%$ \\
Computer serves as tools for supporting & teachers & 30 & 1.53 & .571 & $63.3 \%$ \\
teaching and learning & parent & 30 & 3.47 & .681 & $75 \%$ \\
Computer makes teaching to be & teachers & 30 & 3.60 & .498 & $66.7 \%$ \\
effective & parent & 30 & 2.60 & 1.037 & $85 \%$ \\
Computer is difficult to understand & teachers & 30 & 3.63 & .490 & $76.7 \%$ \\
& parent & 30 & 1.97 & .850 & $86.7 \%$ \\
Computer requires Mental effort & teachers & 30 & 1.50 & .572 & $83.3 \%$ \\
Computer is uncomfortable for teaching & parent & 30 & 1.83 & .950 & $93.3 \%$ \\
Computer is inability to monitor students & teachers & 30 & 2.03 & .809 & $90 \%$ \\
learning & parent & 30 & 1.77 & .774 & $95 \%$ \\
I enjoy using computer & parent & 30 & 1.83 & .834 & $93.3 \%$ \\
& teachers & 30 & 1.77 & .858 & $96.7 \%$ \\
& parent & 30 & 1.90 & .845 & $96.7 \%$ \\
& teachers & 30 & 3.23 & .774 & $98.3 \%$ \\
\hline
\end{tabular}


Table 1: shows the percentage and mean scores on variables administered for parents and teachers. The findings showed that parent obtained the highest percentage on there is no reason for using computer (48.3\%) compare to teachers (40\%), parents also have higher score on computer is taking much time for using (61.7\%), compare to teachers $(56.7 \%)$, it also shows from the same table that parents have higher score on familiar with computer $(66.7 \%)$ than teachers $(63.3 \%)$, parents obtained the highest percentage on computer serves as tools for support teaching and learning $(75 \%)$, compare to teachers $(66.7 \%)$, parents have the higher score on computer makes teaching to be effective (85\%) compare to teachers $(76.7 \%)$, parents have higher score on computer is difficult to understand $(86.7 \%)$, compare to teachers $(83.3 \%)$ parent also have higher score on computer requires mental effort $(93.3 \%)$, than teachers $(90 \%)$, parents obtained higher score on computer is uncomfortable for teaching (95\%), compare to teachers $(93.3 \%)$, parents and teachers have the same scores on computer is inability to monitor students learning $(96.7 \%)$ respectively, parents have higher percentage on enjoy using computer $(98.3 \%)$ compare to teachers $(77 \%)$.

Table 2: comparative analysis of teachers and parents in terms of the attitude towards the use of instructional technology in teaching numeracy to children with mild intellectual disability.

\begin{tabular}{llllllll}
\hline Participants & $N$ & Mean & Std. Deviation & $\begin{array}{l}\text { Std.Error } \\
\text { Mean }\end{array}$ & $d f$ & $t$ & Sig.2.tailed \\
\hline Teachers & 30 & 23.5333 & 3.36035 & .61351 & 58 & .594 & .555 \\
Parents & 30 & 23.0333 & 3.15664 & .57632 & & & \\
\hline
\end{tabular}

Table 2 indicates that teachers had higher mean scores than parents which showed that teachers are more familiar with the usage of instructional technology compare to parents. Although there was no significant difference between the teachers and parents at sig. 2 tailed (.555) within the 0.05 confidence level. This result could be justified by the fact that both participants had been exposed to the computer usage.

Table 3: Comparative analysis between male and female teachers in terms of the attitude towards the use of instructional technology in teaching numeracy to children with mild intellectual disability

\begin{tabular}{cccccccc}
\hline Teachers & $N$ & Mean & $\begin{array}{c}\text { Std. } \\
\text { Deviation }\end{array}$ & $\begin{array}{c}\text { Std. Error } \\
\text { Mean }\end{array}$ & $d f$ & $t$ & $\begin{array}{c}\text { Sig.2 } \\
\text { tailed }\end{array}$ \\
\hline Male & 14 & 22.7143 & 3.19684 & .85439 & 28 & -511 & .613 \\
Female & 16 & 23.3125 & 3.19831 & .79958 & & & \\
\hline
\end{tabular}

The comparative analysis was also conducted in terms of male and female teachers' attitude towards the use of instructional technology in teaching numeracy to children with mild intellectual disability. It is shown from the table above that female teachers have higher mean performance compare to that of male teachers. However, it is evident from the above table that there is no significant difference in the attitude of male and female teachers on the use of instructional technology in teaching numeracy to children with mild intellectual disability. This result could be attributed to the fact that either male or female teachers have been teaching with any form of instructional technology in the classroom.

Table 4: Comparative analysis among parents based on gender on the attitude towards the use of instructional technology in teaching numeracy to children with mild intellectual disability

\begin{tabular}{lccccccc}
\hline Parents & $\mathrm{N}$ & Mean & $\begin{array}{c}\text { Std. } \\
\text { Deviation }\end{array}$ & $\begin{array}{c}\text { Std. Error } \\
\text { Mean }\end{array}$ & df & $\mathrm{t}$ & Sig.2 tailed \\
\hline Male & 15 & 25.0667 & 4.60538 & 1.18910 & 28 & -228 & .822 \\
Female & 15 & 25.400 & 3.31231 & .85524 & & & \\
\hline
\end{tabular}

The table above illustrates that female parents have higher mean score than male parents on the use of instructional technology in assisting the learning of their children at home. It is clear from table 4 that there is no significant difference in their attitude towards the use of instructional technology in teaching numeracy to children with mild intellectual disability.

\section{Discussions and Conclusions}

Based on the findings in this study, it was in realization that parents and teachers have been using computer to teach children with mild intellectual disability. It was also observed that integrating instructional technology into teaching and learning creates rooms for diverse exposures. It was however recommended that in order to make the lives of these children more meaningful as well as increasing their social interaction in the community both parents and teachers must keep encouraging the learning of numeracy with the use of 
instructional technology. Therefore, National Council of Teachers Mathematics, (2000) noted that technology is essential in teaching and learning mathematics which influences mathematical taught as well as enhancing students' learning. Also, female parents have higher mean score than male parents on the use of instructional technology in assisting the learning of their children at home. This is in confirmation with a study conducted by Soeters \& Van Schaik, 2006: Subrahmanyam et al. (2001) who noted that female parents see computer technology as a positive evolution for their children's life and achievement than male parents. The result of the study reveals that female special education teachers have higher mean performance compare to that of male special education teachers. This result agrees with Powers and Blubaugh (2005) finding which observed that female special education teachers are well versed in the issues and applications of technology than male teachers.

\section{REFERENCES}

[1] Uzma, E. (2001). Role of Educational Technology in Teacher Training. Islamabad: Allama Iqbal Open University

[2] Rose, D. \& Meyer, A. (2000) The Future is in the Margins: The Role of Technology and Disability in Educational Reform

[3] Keil, F. C. (2008). Adapted minds and evolved schools. Educational Psychologist. 43 (4), 196-202.

[4] Christensen, R. (2002). Effects of technology integration education on the attitudes of teachers and students. Journal of Research on Technology in Education, 34, 411-433.

[5] Vannatta,\& Fordham, N. (2004). Teacher dispositions as predictors of classroom technology use. Journal of Research on

[6] Technology in Education, 36, 253-271.

[7] Migliorino, N. J., \& Maiden, J. (2004). Educator attitudes toward electronic grading software. Journal of Research on Technology in Education, 36, 193-212.

[8] Smith, K., \& Shotsberger, P. (2001). Web-based teacher education: Improving communication and professional knowledge in preservice and inservice teacher training. Available [online]. Eric Document \#ED459161.

[9] Wernet, S. P., Olliges, R. H., \& Delicath, T.A. (2000). Postcourse evaluation of WebCT (Web Course Tools) classes by social w ork students. Research on Social Work Practice, 10 (4), 487-504.

[10] Almekhlafi, A.G. (2006a). The effect of computer assisted language learning (CALL) on United Arab Emirates English as a foreign language (EFL) school students achievement and attitude. Journal of Interactive Learning Research, 17(2), 121-142.

[11] Almekhlafi, A.G. (2006b). Effectiveness of interactive multimedia environment on language acquisition skills of 6th grade students in the United Arab Emirates. International Journal of Instructional Media, 33 (4), 427, 241.

[12] Lam, Y., \& Lawrence, G. (2002). Teacher-student role redefinition during a computer-based second language project: Are computers catalysts for empowering change? Computer Assisted Language Learning, 15 (3), 295-315.

[13] Kumari, C. J., \& Rao, D. B. (2004). Methods of Teaching: Educational Technology. New Delhi: Discovery Publishing House.

[14] Singh, Y. K. (2005). Instructional Technology in Education. New Delhi: APH publishing corporation. Taylor, L. (n.d.). Educational Theories and Instructional Design Models. Retrieved July 16, 2010, from Simulation Industry Association of Australia: www.siaa.asn.au/get/2396672209.pdf

[15] NCTM (2000). Principles and Standards for School Mathematics. Retrieved July 6, 2011 from http://standards.nctm.org.

[16] Doering, A., Hughes J., \& Huffman, D. (2003). Preservice teachers: Are we thinking with technology?. Journal of Research on Technology in Education, 35(3), 342-361

[17] Hardy, J. T. (2003). An Overview of Empathy. Permanente Journal, 7 (4), pp. 1-14

[18] Mills, S. C., \& Tincher, R. C. (2003). Be the technology: A developmental model for evaluating technology integration in classrooms. Journal of Research on Technology in Education, 35, 382-401.

[19] Pope, M., Hare, D., \& Howard, E. (2002). Technology integration: Closing the gap between what preservice teachers are taught to do and what they can do. Journal of Technology and Teacher Education, 10(2), 101-203.

[20] Roschelle, J., Pea, R., Hoadley, C., Gordin, D., \& Means, B. (2000). Changing how and what children learn in school with computer-based technologies. The Future of Children, 10(2), 76-101.

[21] Dede, C. (2000). Emerging influences of information technology on school curriculum. journal of Curriculum Studies, 32(2), 281303.

[22] Gunter, G. (2001). Making a difference: Using emerging technologies and teaching strategies to restructure an undergraduate technology course for preservice teachers. Education Media International, 38(1), 13-20.

[23] Diem, R. (2000). Can it make a difference? Technology and the social studies. Theory and Research in Social Education, 28(4), 493-501.

[24] Powers, R., \& Blubaugh, W. (2005). Technology in mathematics education: Preparing teachers for the future. . Contemporary Issues in Technology and Teacher Education, 5(3/4), 254 -270.

[25] Marsh J, Brooks G, Hughes J, Ritchie L, S., R., \& K., W. (2005). Digital Beginnings: Young People's Use of Popular Culture, Media and New Technologies. University of Sheffield: Sheffield.

[26] Weber, D. (2006). Media use by infants and toddlers: A potential for play. In Play=Learning. How Play Motivates and Enhances Children's Cognitive and Socioemotional Growth. Singer D, Golinkoff R, Hirsh-Pasek K (eds). Oxford University Press, New York; 169-191.

[27] Shashaani, L., \& Khalili, A. (2001). Gender and computers: similarities and differences in Iranian college students' attitudes toward computers. Computers \& Education, 37, 363-375.

[28] Sutherland, R., Facer, K., Furlong, R., \& Furlong, J. (2000). A new environment for education? The computer in the home. Computers \& Education, , 34, 195-212

[29] Rideout V, \& E., H. (2006). The Media Family: Electronic Media in the Lives of Infants, Toddlers, Preschoolers and Their Parents Kaiser Family Foundation: Menlo Park,CA

[30] Soeters, K. E., \& van Schaik, K. (2006). Children's experiences on the internet. New Library World, 107 (1220/1221), 31-36.

[31] Albirirni, A. (2004).Teachers' attitudes toward information and communication technologies: the case of Syrian EFL teachers Computers \& Education 47 (2006) 373-398 